\title{
Sciendo
}

Acta Veterinaria-Beograd 2021, 71 (4), 462-476

Research article

UDK: 636.2.09:618.1

DOI: $10.2478 /$ acve-2021-0038

\section{ASSESSMENT OF DIFFERENT DIAGNOSTIC METHODS FOR THE IDENTIFICATION OF SUBCLINICAL ENDOMETRITIS IN DAIRY COWS WITH PATHOLOGICAL PUERPERIUM AND THEIR RELIABILITY TO CONCEIVE}

\author{
Bojana BAJAGIĆ ${ }^{*}$, Janko MRKUN ${ }^{2}$, Danijela KIROVSKI ${ }^{3}$, Đorđe SAVIĆ ${ }^{4}$, \\ Draženko BUDIMIR ${ }^{5}$, Jelena MALETIĆ ${ }^{6}$, Milan MALETIĆ
}

\begin{abstract}
${ }^{1}$ Veterinary Department, Ministry of Agriculture, Forestry and Water Management of Republic of Srpska, Banja Luka, Republic of Srpska, Bosnia and Herzegovina; ${ }^{2}$ Clinic for Reproduction and Large Animals, Veterinary Faculty, University of Ljubljana, Ljubljana, Slovenia; ${ }^{3}$ Department for Physiology and Biochemistry, Faculty of Veterinary Medicine, University of Belgrade, Belgrade, Serbia; ${ }^{4}$ Institute for Reproduction of Domestic Animals, Faculty of Agriculture, University of Banja Luka, Banja Luka, Republic of Srpska, Bosnia and Herzegovina; ${ }^{5}$ Faculty of Agriculture, University of Banja Luka, Banja Luka, Republic of Srpska, Bosnia and Herzegovina; ' ${ }^{\circ}$ epartment of Poultry Science, Scientific Veterinary Institute of Serbia, Belgrade, Serbia; ${ }^{7}$ Department for Reproduction, Fertility and Artificial Insemination, Faculty of Veterinary Medicine, University of Belgrade, Belgrade, Serbia
\end{abstract}

(Received 11 October, Accepted 30 November 2021)

The aim of study was to evaluate different methods for subclinical endometritis (SCE) diagnoses and their accuracy to predict pregnancy. The study was performed on 51 postpartum cross breed dairy cows with pathological puerperium. Artificial insemination (AI) was done in spontaneous estrus. Endometrium samples were taken by cytotape (CT), cervical mucus (CM) samples by Metricheck and smears for crystallization degree were obtained at AI day. Blood serum samples for progesterone (P4) concentration determination were taken at $\mathrm{AI}$ day and 17 days later. Cows were examined by ultrasound 35 days after AI to confirm pregnancy. Percent (\%) of polymorphnuclear leukocytes (PMNs) taken by CT were expressed by ROC curve (with cut-off point set at $1 \%$ ). Out of the total of 51 cows involved in the study, $13.73 \%$ true positive and $41.17 \%$ true negative cows were found $(54.90 \%)$. The content of CM sampled with Metricheck was altered in 11 cows $(21.57 \%)$, and one of them was pregnant $(1.96 \%)$. An average macroscopic $\mathrm{CM}$ value for pregnant cows was $0.06 \pm 0.24$ vs. $0.39 \pm 0.79$ for non-pregnant $(\mathrm{p}<0.05)$. An average value of $\mathrm{CM}$ crystallization in pregnant cows was $2.50 \pm 1.04$ vs. $1.85 \pm 1.15$ in non-pregnant $(\mathrm{p}<0.05)$. P4 concentration was not statistically different at AI day, but was statistically significantly higher 17 days later in pregnant cows $(\mathrm{p}=0.002)$. CT alterations may be a reliable diagnostic tool for SCE diagnosis, while macroscopic CM alterations may be used for CE detection. P4 determination is beneficial in pregnancy diagnosis while CM crystallization degree is helpful in determination of best time for AI.

Keywords: cervical mucus, cytotape, Metricheck, subclinical endometritis, pregnancy

\footnotetext{
*Corresponding author: e-mail: VRBASBL078@yahoo.com
} 


\section{INTRODUCTION}

Postpartum endometritis in cattle is a multifactorial disease with high economic impact. Inflammation of the bovine uterus decreases the reproductive performance. Both, clinical (CE) and subclinical endometritis (SCE) are associated with increased days to first service, as well as decreased conception and pregnancy rates, resulting in an increased risk of culling [1,2]. Puerperal disorders (such as dystocia, twins and retained placenta), weakened immune response (due to high milk yield and metabolic problems, mainly ketosis) are main causes of endometritis [3].

As stated by different authors, SCE is characterized by the presence of PMNs on the surface of the endometrium, or in the endometrial lumen, absence of clinical symptoms of endometritis such as vaginal discharge, and reduction in reproductive performance, such as prolonged period from calving to the first insemination, increased insemination index and increased prevalence of early embryonal loss [2,4,5]. Since the appearance of clinical symptoms is absent in SCE, the diagnosis is complicated. There are many diagnostic methods for SCE identification, but only few of them are widely used in field conditions. Cytological analysis of endometrial smears, in order to determine the increased presence of PMNs, and macroscopic visual analysis of the cervical mucus (CM) samples for the evaluation of CM quality parameters, such as cleanliness, color, quantity and presence of pus, blood and other impurities are often used for the evaluation of SCE presence [3,5-7]. This method, combined with the determination of progesterone (P4) concentration, obtained at the time of insemination, can be used as reliable methods of pregnancy prediction.

There are some controversies among authors in relation to the time of the postpartum period from which a physiological endometrial inflammation process (uterine „,cleaning“) should be considered as a pathological SCE [8]. Therefore, depending on the sampling period after calving, different studies established a different degree of PMNs infiltration as the cutoff point for SCE diagnosis [7-9]. Some authors suggest a threshold range which indicates the presence of SCE from $4 \%$ to $18 \%[4,10,11]$, but most studies use 5\% PMNs as the cutoff value [12]. The time of endometrial sampling for SCE diagnosis is different in various studies. Many authors take samples for PMNs determination 3 to 5 weeks or 5 to 7 weeks after calving [8]. At that time uterine involution is not finished yet, so many cows have spontaneous recovery by the end of puerperium [12]. Bearing in mind that the uterine and endometrium health state at the time of AI can be taken as the key factors for pregnancy, Pascottini et al. $[6,13]$ recommend endometrium sampling at the time of $\mathrm{AI}$ as the most relevant moment for the prediction of success of AI, and have developed a CT technique for taking endometrium samples while performing AI. According to these authors, the advantage of sampling while performing AI is that this procedure does not affect the pregnancy rate [13], even if there is a risk that the insemination procedure itself can induce a PMNs response in the endometrium [14]. Also, the authors state that these samples are of high-quality, so their reliability in the prediction of pregnancy is also high [9]. 
The presence of pus or blood, and any other contaminants can be easily detected by macroscopic visual examination of CM samples. Regardless the technique used for sampling it is a simple and cheap method for the detection of uterine disorders. The secretions from the uterus frequently accumulate in the fornix of the cranial vagina and are easily retrieved and checked [12]. CM samples for macroscopic visual examination are previously taken by vaginoscopy, but in the late 2000's a device for CM sampling "Metricheck" was developed by Simcrotech, Hamilton, New Zealand (http://www.simcrotech.co.nz/products). Similar to the classification of CM samples taken by vaginoscopy, Sheldon et al. [16] propose a classification of CM samples taken by Metricheck on a scale from 0 to 3 (0 - clear or translucent mucus (healthy cows); 1 - mucus containing patches of white or off-white pus; 2 - discharge containing less than $50 \%$ white or off-white mucopurulent material; 3 - discharge composed of more than $50 \%$ white or yellow pus, or hemorrhagic). When Metricheck CM evaluation was compared with vaginoscopy as the standard method, Metricheck had a higher sensitivity, but slightly lower specificity, than vaginoscopy [3]. According to these authors, this method is faster than vaginoscopy, which gives it superiority in studies where large number of animals has to be examined.

Bovine $\mathrm{CM}$ changes its biochemical composition and biophysical properties due to the variations in sex steroid levels during the estrous cycle. As a consequence of estrogen rise, CM is produced in larger amounts at estrus - a stage of cycle characterized by an increase in mucus crystallization degree when observed under light microscopy [17]. It is known that alterations in CM ultrastructure, due to inflammatory processes or endocrine imbalances are linked to fertility problems (lack of conception) in cows, so changes in crystallization degree can be used as an indicator of these disorders [18].

Circulating P4 concentration is determined by a balance between P4 production, primarily by the corpus luteum (CL), and P4 metabolism, primarily by the liver. Even small increases in $\mathrm{P} 4$ near the time of $\mathrm{AI}$ were associated with dramatic reductions in fertility, either in cows bred to natural estrus or after timed AI protocols [19].

The aim of study was to evaluate different methods to diagnose SCE in postpartum dairy cows with pathological puerperium and its accuracy to predict pregnancy.

\section{MATERIALS AND METHODS}

The fifty-one cross-breed calved dairy cows (Holstein x Simmental cross-breed, 20 primiparous and 31 multiparous cows), kept in farm conditions (farm size 110 dairy cows) were included in the study. Cows were kept in a free stall system, and milked twice a day. Average daily milk production was 20 liters, and cows were fed with TMR ration $(3 \mathrm{~kg}$ of hay, $28 \mathrm{~kg}$ of corn silage, $7 \mathrm{~kg}$ of pea silage and $5 \mathrm{~kg}$ of concentrate with $18 \%$ of proteins). In order to achieve pregnancy and for study purposes, up to two AI attempts were performed on the cows. Among them, there were first-service heifers $(n=23)$, second to third AI attempts or repeat breeders $(n=23)$ and more than 
the fourth AI attempts $(n=5)$. Cows that achieved pregnancy were considered as the pregnant group, and rest of them as non-pregnant group. Data on the health and reproductive status of cows were taken from the records kept at the farm. Most of the animals (31 out of 51 included in the study) had been diagnosed with pathological problems in the puerperium (9 cows had clinical endometritis associated with retained placenta, and 22 cows had vaginitis, mastitis and ketosis) and they were treated with proper medications (antibiotics, corticosteroids, analgetics, and vitamins, according to diagnosis). The time of AI was determined on the basis of the time of the most pronounced signs of estrus, and the cows were inseminated using the standard bimanual method. All cows were inseminated with frozen semen, which has been proved to be highly fertile.

Samples for endometrial cytological status examination were collected at the time of insemination, using the cytotype (CT) technique. CT was introduced into the uterus through the vagina and cervix, with help of insemination catheter. When CT was at the desired location, it was pulled out of the guide and rotated clockwise to collect the endometrial cells. The top of the CT was then returned to its plastic wrap to avoid contamination with the cervical contents. The collected content from the top of CT was then carefully smeared on sterile microscopic slides and after air drying, stained with a Giemsa stain. Later on it was observed under a Nikon Eclipse Ci/Ni, Japan, microscope at 400x magnification in the laboratory, to identify the types and presence of different cell types, with emphasis on PMNs. At least 100 cells were counted in 10 fields, with special attention paid to the presence of PMNs. A number of PMNs has been expressed by a ROC curve, with determination of $1 \%$ PMNs as a cut-off point.

Samples of cervical mucus (CM), taken with Metricheck device, were evaluated according to the classification described by Sheldon et al. [16], on a scale from 0 to 3 (0 - clear or translucent mucus (healthy cows); 1 - mucus containing patches of white or off-white pus; 2 - discharge containing less than $50 \%$ white or off-white mucopurulent material; 3 - discharge composed of more than $50 \%$ white or yellow pus or is hemorrhagic). The Metricheck device consists of a very durable construction made of $50 \mathrm{~cm}$ long stainless steel, with a hemispherical $4 \mathrm{~cm}$ ("cup" shape), rubber/ silicone attachment that can be easily changed. Metricheck was carefully introduced into the cow's vagina at a $45^{\circ}$ angle, after cleaning the vulva's labia, going forward to the cranial borders of the cervical fornix until it stopped, collecting the contents, and then carefully pulled out of the reproductive tract upwards at an angle of $30^{\circ}$ to the outer environment, taking into account that any content in the Metricheck hemisphere remains in it. The content scooped in hemisphere of the device was the subject of visual evaluation and scoring.

CM samples for determination of the crystallization degree were taken with insemination catheter cover, and after being smeared on a sterile microscope slide, air-dried and observed under a Nikon Eclipse Ci/Ni, Japan at 200x magnifications. Assessment of the degree of crystallization was performed according Bishnoi et al. [20] on a scale from 0 to 4 ( 0 - absences of crystalline formations; 1 - formation of 
atypical crystals only; 2 - many atypical and some typical fern-like crystals; 3 - the formation of typical fern-frond crystals; 4 - the typical fern frond crystals).

Blood samples were taken twice from coccygeal vein (vena coccygea), on the day of insemination and 17 days later, in sterile vacutainers with blood clot activator. Extracted blood sera were frozen and stored in the refrigerator at $-19^{\circ} \mathrm{C}$ in Eppendorf PCR micro tubes $(0.2 \mathrm{ml}$ volume). Thawed samples were later analyzed in the laboratory for determination of P4 concentration. Blood serum P4 concentration was determined using an automated quantitative fluorescent enzyme-linked immunoassay on a mini VIDAS $®$ instrument, (Biomerieux, France).

Cows were diagnosed as non-pregnant when they showed signs of estrus in three weeks after AI or when it was determined that they were non-pregnant by diagnostic ultrasound method performed 35 days after AI. Transrectal diagnostic ultrasound method for pregnancy determination was performed with ultrasound device DP-20 VET, manufactured by Mindray, China.

The experimental procedure has been approved by Veterinary Directorate Ethics Committee of Ministry of Agriculture, Forestry and Water Management of the Republic of Serbia (Decision number: 323-07 -03667/2021-05).

\section{Statistical analysis of data}

The normality of data distribution was tested using the Shapiro-Wilk test. All data were normally distributed $(\mathrm{P}>0.05)$, except data for $\mathrm{P} 4$ concentrations. The values of homogenous data were presented as mean \pm SD (standard deviation) and for heterogeneous data presented as medians and lower-upper quartiles. ROC curve was used in this study to present the number of counted PMNs in endometrial cytology (EC) samples of cows. It is a graph of sensitivity (y-axis) versus specificity (x-axis).

\section{RESULTS}

\section{Cytological state of the endometrium and its relation for the identification of SCE}

The cytological state of the endometrium and presence of SCE were evaluated by counting PMNs in the endometrial smears taken with CT, and stained with Giemsa, to visualize the cells (Figure 1).

\section{Creation of the ROC curve to assess the PMNs cut-off point for SCE diagnosis}

According to the ROC curve, made on the basis of the obtained results for the sensitivity and specificity, a cut-off point of $1 \%$ PMNs was determined (Figure 2). At cut-off point of $1 \%$ PMNs in terms of sensitivity, the proportion of those cows which were truly pregnant (testing showed they were pregnant) was 0.38 . At cut-off point of $1 \%$ PMNs in terms of specificity, the proportion of those cows which were not pregnant (and tests showed that they were not pregnant) was 0.63. 


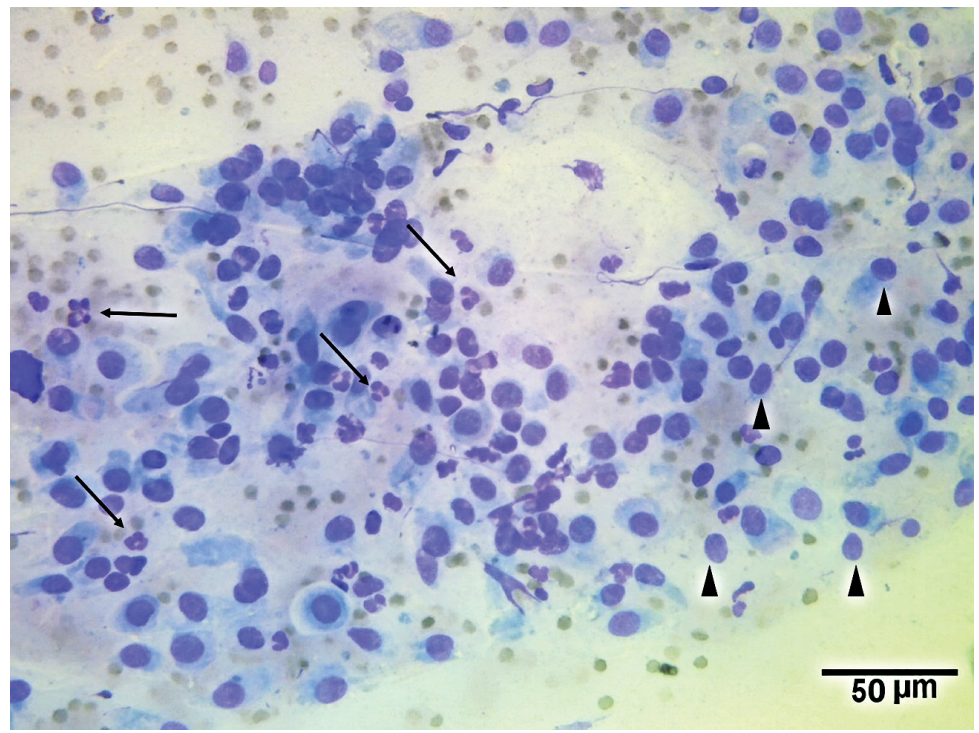

Figure 1. Endometrial cytology. (a) polymorphonuclear granulocytes (PMN) (arrow), Giemsa, $\mathrm{x} 400$. (b) endometrial cells (arrow head), Cytotype technique (CT), Giemsa, x400

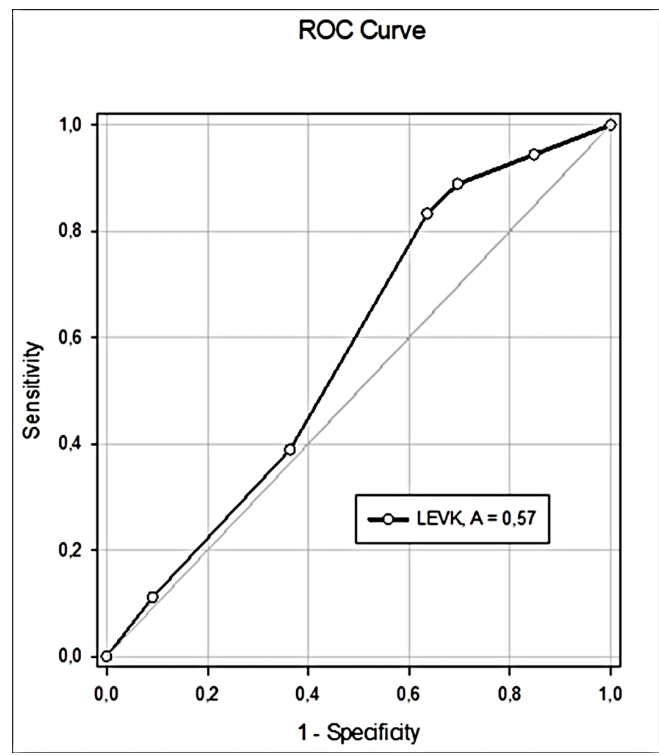

Figure 2. ROC curve for assessment of cut-off point for PMNs \% for SCE diagnosis

If the criteria for a positive test is higher, lower is the sensitivity and higher is its specificity. Since a cut- off point of $1 \%$ PMNs was determined in this study, where the sensitivity is lower and specificity is higher on the obtained ROC curve, criteria for a positive test had been higher. 
At cut-off point of $1 \%$ PMNs, $13.73 \%$ true positive cows and $41.17 \%$ of true negative cows were found, which is $54.90 \%$ of the total number of cows involved in this study.

\section{Macroscopic CM evaluation and its relation for identification of SCE}

CM samples, taken with Metricheck device, were evaluated according to classification given by Sheldon et al. [16]. Examples of CM visual scores taken from the examined cows are presented in Figure 3. From the total of 51 examined cows 18 (35.29\%) of them were diagnosed as pregnant, $11(21.57 \%)$ cows showed altered CM score (value different from 0$)$, and only one of them $(9.09 \%)$ was later diagnosed as pregnant. In this study a CM visual score 0 was found in 41 cows, score 1 in eight cows and score 3 in two cows. None of the examined cows had CM visual score 2. Average CM score for pregnant cows was $0.06 \pm 0.24$, versus $0.39 \pm 0.79$ in non-pregnant cows, and these values were significantly different $(\mathrm{p}<0.05)$.

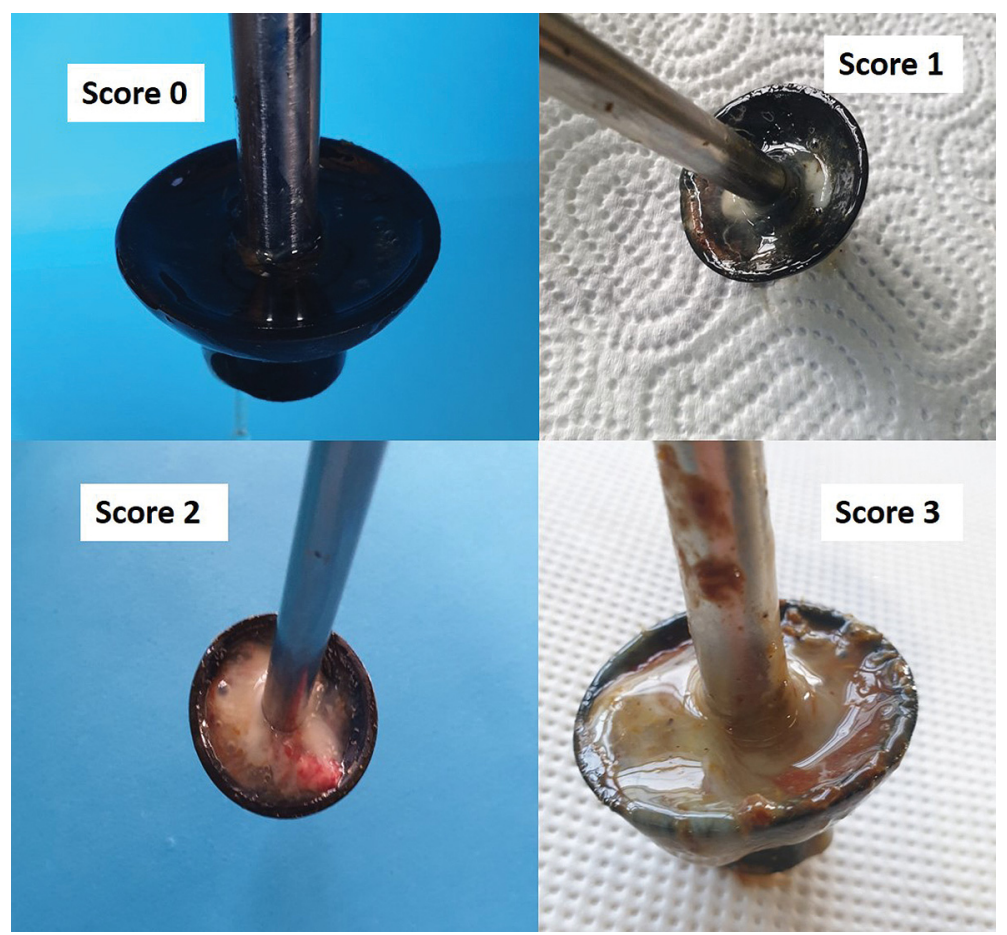

Figure 3. Macroscopic CM evaluation (Score 0 - clear or translucent mucus (healthy cows); Score 1 - mucus containing patches of white or off-white pus; Score 2 - discharge containing less than $50 \%$ white or off-white mucopurulent material; Score $\mathbf{3}$ - discharge composed of more than $50 \%$ white or yellow pus or is hemorrhagic) 


\section{$\mathrm{CM}$ crystallization degree and its relation to pregnancy rate}

CM samples for the determination of the crystallization degree were evaluated according to the description given by Bishnoi et al [20]. Examples of CM crystallization scores taken from the examined cows are presented in Figure 4.

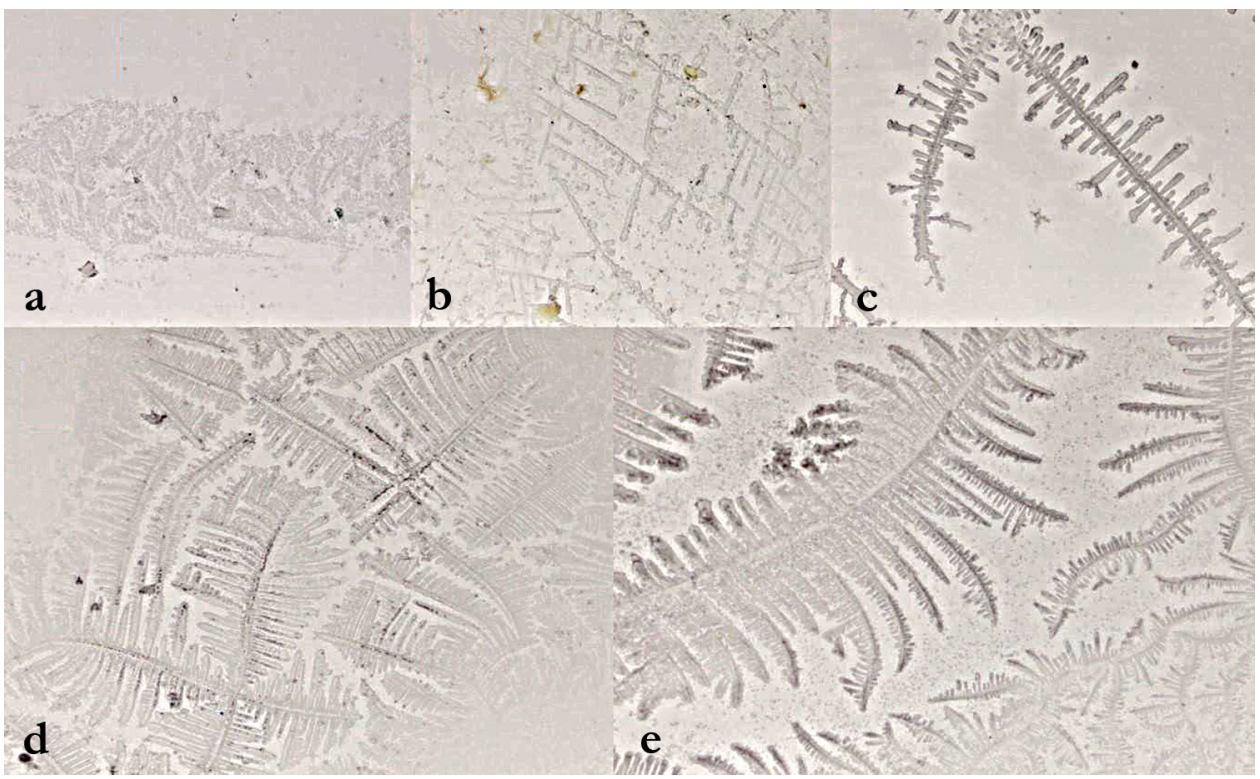

Figure 4. Crystal formation of cervical mucus (CM). (a) Score 0 - absence of crystal formation. (b) Score 1 - formation of atypical crystals. (c) Score 2 - typical and atypical crystals. (d) Score 3 - formation of fern-frond crystals. (e) Score 4 - typical fern-frond crystals (magnification 200x)

From the total of 51 examined cow $18(35.29 \%)$ of them were diagnosed as pregnant, six cows $(11.76 \%)$ had crystallization score 0, eight cows, $(15.69 \%)$ had score 1,18 cows $(35.29 \%)$ had score 2,14 cows $(27.45 \%)$ had score 3 , and five cows $(9.80 \%)$ had crystallization score 4 . Average CM crystallization degree score for pregnant cows was $2.50 \pm 1.04$, versus $1.85 \pm 1.15$ in non- pregnant cows, and these values were significantly different $(\mathrm{p}<0.05)$.

\section{Progesterone concentration and its relation to conception rate}

The average concentration of $\mathrm{P} 4$ in the blood of pregnant and non-pregnant cows on the day of AI did not show statistical significance of differences (Table 1), unlike that found $17^{\text {th }}$ days after, when an average concentration of P4 in pregnant cows compared to non-pregnant cows (Table 2) was statistically significantly higher ( $\mathrm{p}=$ 0.002). The average concentration of $\mathrm{P} 4$ on $17^{\text {th }}$ day after $\mathrm{AI}$ in cows with realized conception was significantly $(\mathrm{p}=0.0002)$ higher than P4 concentration determined on day 0 in the same cows (Table 3). The results of this study indicate a high degree of individual variations in the concentration of $\mathrm{P} 4$ in both groups of cows, especially on the day of insemination. 
Table 1. P4 value on day 0 of estrus in pregnant and non-pregnant cows

\begin{tabular}{cccccc}
\hline \multirow{2}{*}{ Progesterone } & \multicolumn{2}{c}{ Pregnant cows } & \multicolumn{2}{c}{ Non-pregnant cows } & \multirow{2}{*}{ P value } \\
\cline { 2 - 5 } & Median & $\begin{array}{c}\text { Lower-Upper } \\
\text { quartile }\end{array}$ & Median & $\begin{array}{c}\text { Lower-Upper } \\
\text { quartile }\end{array}$ & \\
\hline Day 0 & 0.25 & $0.25-0.57$ & 0.27 & $0.25-0.54$ & $\mathrm{P}=0.498$ \\
\hline
\end{tabular}

Table 2. P4 value on the $17^{\text {th }}$ day of estrus in pregnant and non-pregnant cows

\begin{tabular}{cccccc}
\hline \multirow{2}{*}{ Progesterone } & \multicolumn{2}{c}{ Pregnant cows } & \multicolumn{2}{c}{ Non-pregnant cows } & \multirow{2}{*}{ P value } \\
\cline { 2 - 5 } & Median & $\begin{array}{c}\text { Lower-Upper } \\
\text { quartile }\end{array}$ & Median & $\begin{array}{c}\text { Lower-Upper } \\
\text { quartile }\end{array}$ & \\
\hline Day 0 & 8.58 & $7.65-11.08$ & 4.58 & $1.13-8.07$ & $\mathrm{P}=0.002$ \\
\hline
\end{tabular}

Table 3. P4 value on day 0 and on the $17^{\text {th }}$ day of estrus in pregnant cows

\begin{tabular}{lccccc}
\hline \multirow{2}{*}{ Progesterone } & \multicolumn{2}{c}{ Day 0 } & \multicolumn{2}{c}{ Day 17 } & \multirow{2}{*}{ P value } \\
\cline { 2 - 5 } & Median & $\begin{array}{c}\text { Lower-Upper } \\
\text { quartile }\end{array}$ & Median & $\begin{array}{c}\text { Lower-Upper } \\
\text { quartile }\end{array}$ & \\
\hline Pregnant cows & 0.25 & $0.25-0.57$ & 8.58 & $7.65-11.08$ & $\mathrm{P}=0.0002$ \\
\hline
\end{tabular}

\section{DISCUSSION}

Opposite to clinical endometritis, which is defined by the presence of pus in the vagina and vaginal discharge during 21 days or more postpartum, often being associated with delayed uterine involution [21], cows with SCE do not show any clinical sign of endometritis, so reliable methods for diagnosis such condition are needed. This study targeted an evaluation of different methods for diagnosis of SCE and their reliability in the prediction of establishing pregnancy after AI. Each method was analyzed individually for their usefulness and application in practice with the obtained conception rate.

Limited literature data are available regarding the use of CT technique in diagnosing SCE and following pregnancy rate [22], since it was first described by Pascottini (9] in 2015, as a novel technique for EC sample collection. CT has been the only method for EC sampling which can be done at the same time while doing AI. By our knowledge, EC sampling at AI with CT has been so far published two times, by Pascottini et al. [9] and Diaz-Lundahl et al. [2] on Norwegian Red cows. Both studies counted the number of PMNs from 300 cells, as we did from 100 cells. Same as Pascottini et al. [13], optimal cut-off point in this study was set at 1\%, while Diaz-Lundahl et al. [2] set the optimal cut-off at 3\%. Sensitivity and specificity obtained by ROC curve in Pascottini et al. [13] study was equal to $33.8 \%$ and $88.6 \%$, respectively, while in Diaz-Lundahl et al. [2] study was $32.4 \%$ and $74.9 \%$, respectively. The results in this study showed that sensitivity was 0.38 and specificity 0.63 , while in other studies done by Pascottini et al. [6] sensitivity and specificity at the same cut-off point were 0.12 and 0.95 , respectively. 
Pascottini et al. [6] found 7.86\% (39/496) of uterine samples with SCE taken from nulliparous heifers at the time of insemination, but stated that even though they had relatively high number of AI samples in the study the results should be interpreted with caution because of the small number of SCE positive uteri. Results of that study indicate a conception rate of $62.8 \%$ in SCE negative samples and $38.46 \%$ in SCE positive samples.

The results in this study showed that $62.74 \%(32 / 51)$ of cows had SCE at the time of AI (in a study published by Diaz-Lundahl et al. [2] it was $28.0 \%$ ). The prevalence of SCE in this study is higher than in other studies cited, probably due to the fact that this study was carried out on cows with a history of puerperal problems. The conception rate for SCE negative cows in this study was 36.84\% (7/19), and for SCE positive cows was $34.37 \%$ (11/32). Successful pregnancy, following the first AI, was recorded in $53.4 \%$ and $62.2 \%$ of cows were positive or negative for SCE, respectively [2]. Studies that reported no correlation between PMNs in the endometrium and pregnancy outcome suggest that their results might have been due to one or more of the following contributing factors: a lower bacterial load, a more thorough reproduction management in their study designs, or a more effective immune system of the animals $[2,23,24]$. The study where EC sampling was done $4 \mathrm{~h}$ after AI with CT [1], demonstrated at first that cows with high proportions of endometrial PMNs $(>15 \%$ PMNs) have a decreased first service conception rate, which might be indicative of SCE presence, but further analyses showed that results were affected by parity, but not by $\%$ of PMNs.

Regarding the results obtained in this study by Metricheck device, it was indicative that from $35.29 \%(18 / 51)$ of cows which were later diagnosed as pregnant, 11 of them $(21.57 \%$ ) showed altered CM visual score (value different from 0 ), and only one $(9.09 \%)$ was later diagnosed as pregnant. Judging by the results obtained in this study, cows that had a CM visual score of 0 should be pregnant since they did not show any changes of the uterus content, but some of them did not conceive, which is indicative of some other problems. In a study done by Diaz-Lundahl et al. [2] there was no difference in pregnancy rate after first AI for cows with clear and opaque mucus $(60.4 \%$ and $62.3 \%$, respectively). For cows with a score 2,2 were pregnant, 4 non-pregnant, 1 had uncertain pregnancy status, and 3 cows were inseminated during the luteal phase. Uterine lavage (uterine cytology) appears to be the most efficient method for the diagnosis of endometritis, followed by Metricheck, ultrasonography and vaginoscopy [12], but the Metricheck device is a more reliable method in endometritis diagnosing then examination with a speculum or a gloved hand [15]. Also, this novel device appears to have a higher sensitivity, but slightly lower specificity, than vaginoscopy [3]. Additionally, the device is faster to use than vaginoscopy, offering advantages where large numbers of animals need to be examined. In this study, 45.45\% (5/11) cows which had abnormal CM visual score had higher risk for developing SCE, than cows which had normal CM visual score 54.54\% (6/11). 
CM samples for the determination of the crystallization degree in this study clearly showed that this technique should be used as a cheap and easy method for the determination of the best time for AI if other parameters are fulfilled. Crystallization score 0 was found in 6 cows $(11.76 \%)$, score 1 in 8 cows $(15.69 \%), 18(35.29 \%)$ cows had score $2,14(27.45 \%)$ cows score 3 , and $5(9.80 \%)$ cows had crystallization score 4 . There was no pregnancy in cows with score 0 . In the group of cows with formation of typical fern-frond crystals, and formed fern crystals (score 3 and 4) there were 10 pregnant cows, which are $55.55 \%$ of obtained pregnancies. A typical arborization pattern of cervical mucus was observed in $54.25 \%$ of the estruses, and significantly higher conception rate $(54.90 \%)$ was observed in buffaloes inseminated with typical arborization pattern of cervical mucus as compared to atypical arborization pattern $(20.00 \%)$ and no conception was recorded in the estruses with nil arborization patterns [27].

The results for P4 level in this study at the time of AI showed that $61.11 \%(11 / 18)$ cows which had P4 concentration $<0.25 \mathrm{ng} / \mathrm{ml}(<0.625 \mathrm{nmol} / \mathrm{l})$ as threshold point, had a higher pregnancy rate but its concentration remains high 17 days later. Seventeen cows had P4 above threshold point at the AI time, but on day 17, P4 concentration declined rapidly, which results with no pregnancy in 51.51\% (17/33) cows. Cows with P4 levels of $>0.5 \mathrm{ng} / \mathrm{mL}$ at the time of AI had a lower conception rate $(18.2 \%)$ than cows with P4 levels $\leq 0.50 \mathrm{ng} / \mathrm{mL}(32.8 \%)$ [25]. Diaz-Lundahl et al. [2] collected milk samples for P4 analysis twice, at the AI time and 21 days later. P4 concentration at AI time in their study was $\leq 3.0 \mathrm{ng} / \mathrm{mL}$ (threshold point) in $96.1 \%$ cows. A P4 content of $\leq 3.0 \mathrm{ng} / \mathrm{mL} 21 \mathrm{~d}$ after first AI was evaluated as return to estrus. In the research done by Purschke [26], no correlation between fertility and P4 concentrations at time of ovulation was found.

According to Båge [28] heifers that did not become pregnant after AI had significantly higher basal P4 concentrations $(>0.5 \mathrm{nmol} / \mathrm{l}$, ) at AI time, so-called suprabasal concentrations, compared with those which conceived after AI.

Pregnancy rate from first AI in this study population was $35.29 \%$, which is lower, compared to the pregnancy rates of $59.8 \%$ in the study done by Diaz-Lundahl et al. [2], or $43 \%$ reported by Pascottini et al. [13]. The results in this study also showed that $66.6 \%(12 / 18)$ cows with pathological puerperium in the past, and treated with a conventional therapy, successfully achieved pregnancy, 48.37\% (15/31) were SCE negative and $51.61 \%(16 / 31)$ SCE positive. Out of the 51 cows included in the study, 31 cows were sick and treated on the farm.

\section{CONCLUSIONS}

The results of this study showed that the EC sampling done by CT is a more reliable method for diagnosing SCE, comparing to Metricheck device which is cheaper and easier to perform, but SCE can be misdiagnosed with other reproductive diseases 
and cows can be treated incorrectly. Moreover, the presence of PMNs cannot be used as the only diagnostic parameter for SCE diagnosis. Additional harmonization is needed in future between the determination of the limit value for PMNs \% cut-off point, the method of counting, the total number of counted cells, repetition of PMNs counting etc. The results in this study showed that P4 value 17 days after AI can be very predictable factor of pregnancy establishment and CM crystallization should be used as an additional method to determine the best time for AI.

\section{Acknowledgments}

The study was supported by the Ministry of Education, Science and Technological Development of the Republic of Serbia (Contract number 451-03-9/2021-14). We appreciate to Mr. Andrew Shepherd from the company Simcro DATAMARS, New Zealand, for providing free of charge Metricheck device with the words "I am a firm believer in research and development ".

\section{Authors' contributions}

BB, ĐS, MM, JMaletić, DK, JMrkun and DB conceived all presented studies and planned the experiments. MM supervised the entire work. BB and ĐS took samples at the farm, prepared the samples and analyzed them in the laboratory. JMaletic verified PMNL(s) counting and provided data. JM, MM and DB verified the Metricheck score and provided data. DB provided all data from the farm including health status and nutrition. JMrkun developed the ROC curve. DK provided all statistical data. BB wrote the paper with the input of all authors. All authors provided critical feedback and helped to shape the research and final paper.

\section{Declaration of conflicting interests}

The author(s) declared no potential conflicts of interest with respect to the research, authorship, and/or publication of this article.

\section{REFERENCES}

1. Kaufmann TB, Drillich M, Tenhagen BA, Forderung D, Heuwieser W: Prevalence of bovine subclinical endometritis $4 \mathrm{~h}$ after insemination and its effects on first service conception rate. Theriogenology 2009, 71(2):385-391.

2. Diaz-Lundahl S, Garmo RT, Gillund P, Klem TB, Waldmann A, Krogenæs AK: Prevalence, risk factors, and effects on fertility of cytological endometritis at the time of insemination in Norwegian Red cows. J Dairy Sci 2021, 104(6):6961-6974.

3. McDougall S, Macaulay R, Compton C: Association between endometritis diagnosis using a novel intravaginal device and reproductive performance in dairy cattle. Anim Reprod Sci 2007, 99(1-2):9-23. 
4. Kasimanickam R, Duffield TF, Foster RA, Gartley CJ, Leslie KE, Walton JS, Johnson WH. Endometrial cytology and ultrasonography for the detection of subclinical endometritis in postpartum dairy cows. Theriogenology 2004, 62(1-2):9-23.

5. Sheldon, IM, Owens SE: Postpartum uterine infection and endometritis in dairy cattle. Anim Reprod 2017,14 (3):622-629

6. Pascottini OB, Hostens M, Dini P, Van Eetvelde M, Vercauteren P, Opsomer G: Prevalence of cytological endometritis and effect on pregnancy outcomes at the time of insemination in nulliparous dairy heifers. J Dairy Sci 2016, 99(11):9051-9056.

7. Wagener K, Gabler C, Drillich M. A review of the ongoing discussion about definition, diagnosis and pathomechanism of subclinical endometritis in dairy cows. Theriogenology 2017, 94:21-30.

8. Arias LAQ, Fernández MV, González JJB, López MB, Herradón PG, Martínez AIP: Subclinical endometritis in dairy cattle. in: Payan-Carreira R. New Insights Into Theriogenology. Intech 2018, 79-97

9. Pascottini OB, Dini P, Hostens M, Ducatelle R, Opsomer G: A novel cytologic sampling technique to diagnose subclinical endometritis and comparison of staining methods for endometrial cytology samples in dairy cows. Theriogenology 2015, 84(8):1438-1446.

10. Gilbert RO, Shin ST, Guard CL, Erb HN, Frajblat M: Prevalence of endometritis and its effects on reproductive performance of dairy cows. Theriogenology 2005, 64(9):18791888.

11. Barlund CS, Carruthers TD, Waldner CL, Palmer CW: A comparison of diagnostic techniques for postpartum endometritis in dairy cattle. Theriogenology 2008, 69(6):714723.

12. Kumar P, Purohit GN, Mehta JS: Diagnosis of endometritis in cows using Metricheck, uterine cytology and ultrasonography and efficacy of different treatments. Veterinary Practitioner 2013, 14 (2): 351-354

13. Pascottini OB, Hostens M, Sys P, Vercauteren P, Opsomer G: Cytological endometritis at artificial insemination in dairy cows: Prevalence and effect on pregnancy outcome. J Dairy Sci 2017a,100(1):588-597.

14. Pascottini OB, Hostens M, Sys P, Vercauteren P, Opsomer G: Risk factors associated with cytological endometritis diagnosed at artificial insemination in dairy cows. Theriogenology 2017b, 92:1-5.

15. Pleticha S, Drillich M, Heuwieser W: Evaluation of the Metricheck device and the gloved hand for the diagnosis of clinical endometritis in dairy cows. J Dairy Sci 2009, 92(11):54295435 .

16. Sheldon IM, Lewis GS, LeBlanc S, Gilbert RO: Defining postpartum uterine disease in cattle. Theriogenology 2006, 65(8):1516-1530.

17. Cortés ME, González F, Vigil P. Crystallization of Bovine Cervical Mucus at Oestrus: An Update. Rev Med Vet. 2014, 28: 103-116.

18. López-Gatius F, Labérnia J, Santolaria P, Rutllant J, López-Béjar M: The relationship of the rheological behavior of the cervical fluid at the time of insemination to the conception rate in dairy cows. Theriogenology 1997, 48(5):865-871.

19. Wiltbank, M, Souza, A, Carvalho, P, Cunha, A, Giordano, J, Fricke, P, Diskin, M: Physiological and practical effects of progesterone on reproduction in dairy cattle. Animal 2014, 8(S1), 70-81. 
20. Bishnoi BL, Vyas KK, Dwaraknath PK: Note on spinnbarkeit and crystallization pattern of bovine cervical mucus during oestrus. Indian J Anim Sci 1982, 52(6): 438-440

21. Sheldon IM, Noakes DE: Comparison of three treatments for bovine endometritis. Vet Rec 1998,142:575-579.

22. Ramirez-Garzon, O, Soares Magalhaes, R, Satake, N, Hill, J, Jimenez, C, Holland, MK, McGowan, M: Effect of Endometrial Sampling Procedures on Subsequent Pregnancy Rate of Cattle. Animals : an Open Access Journal from MDPI 2021, 11, n. pag.

23. Plöntzke J, Madoz LV, De la Sota RL, Drillich M, Heuwieser W: Subclinical endometritis and its impact on reproductive performance in grazing dairy cattle in Argentina. Anim Reprod Sci 2010, 122(1-2):52-57.

24. Prunner I, Wagener K, Pothmann H, Ehling-Schulz M, Drillich M: Risk factors for uterine diseases on small- and medium-sized dairy farms determined by clinical, bacteriological, and cytological examinations. Theriogenology 2014, 82(6):857-865.

25. Moreno-Oliva P, Montaldo-Valdenegro H, García-Ortiz C, Hernández-Cerón J: Serum progesterone concentrations at the insemination time and pregnancy rate in dairy cows, AbanicoVet 2016, 6(2):22-29.

26. Purschke S: Effects of suprabasal progesterone levels and negative energy balance on estrous activity and fertility in dairy cows. Inaugural Dissertation, Vetsuisse Faculty, University of Zürich, Clinic of Reproductive Medicine, 2013.

27. Verma KK, Prasad S, Kumaresan A, Mohanty TK, Layek SS, Patbandha TK, Chand S: Characterization of physico-chemical properties of cervical mucus in relation to parity and conception rate in Murrah buffaloes, Veterinary World 2014, 7(7): 467-471

28. Båge R: Conception rates after AI in Swedish red and white dairy heifers: relationship with progesterone concentrations at AI. Reprod Domest Anim 2003, 38(3):199-203.

\title{
PROCENA RAZLIČITIH DIJAGNOSTIČKIH METODA ZA IDENTIFIKACIJU SUPKLINIČKOG ENDOMETRITISA MLEČNIH KRAVA SA PATOLOŠKIM PUERPERIJUMOM I NJIHOVA POUZDANOST U PREDIKCIJI GRAVIDITETA
}

\author{
Bojana BAJAGIĆ, Janko MRKUN, Danijela KIROVSKI, Đorđe SAVIĆ, \\ Draženko BUDIMIR, Jelena MALETIĆ, Milan MALETIĆ
}

Cilj studije bio je procena različitih metoda za dijagnostiku supkliničkog endometritisa (SKE) i njihove pouzdanosti za predviđanje graviditeta. U studiju je bila uključena 51 postpartalna mlečna krava mešane rase sa patološkim puerperijem. Veštačko osemenjavanje (VO) rađeno je u spontanom estrusu. Na dan VO uzeti su uzorci endometrijuma dobijeni cytotape (CT) tehnikom, kao i uzorci cervikalne sluzi (CS) dobijeni upotrebom Metričeka. Razmaz CS, urađen isti dan, korišten je za ispitivanje stepena kristalizacije. Uzorci krvi za odredivanje koncentracije progesterona (P4) uzeti su na dan VO i 17 dana kasnije. Krave su pregledane ultrazvukom 35 dana nakon VO radi potvrdivanja graviditeta. Procenat (\%) polimorfonuklearnih leukocita (PMNs) dobi- 
jenih CT tehnikom je izražen ROC krivom (granična vrednost je određena na 1\%). Od ukupno 54,90\% krava uključenih u studiju, utvrđeno je 13,73\% stvarno pozitivnih i 41,17\% stvarno negativnih krava. Izmenjen sadržaj CS uzorkovane Metričekom utvrđen je kod jedanaest krava $(21,57 \%)$, ali samo jedna $(1,96 \%)$ je bila gravidna. Prosečna makroskopska vrednost CS kod gravidnih krava je bila 0,06 $\pm 0,24$ u odnosu na $0,39 \pm 0,79$ kod negravidnih $(\mathrm{p}<0,05)$. Prosečna vrednost kristalizacije CS kod gravid-

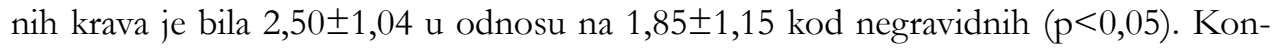
centracija P4 nije se statistički razlikovala na dan VO, ali je bila statistički značajno veća 17 dana kasnije kod gravidnih životinja $(\mathrm{p}=0.002)$. Promene utvrđene CT mogu biti indikator SKE, a promene CS dobijene Metričekom mogu biti indikator kliničkog endometritisa. Određivanje P4 korisno je u dijagnostici graviditeta, a kristalizacija CS može se koristiti kao pomoćni metod za određivanje najpovoljnijeg vremena za VO. 